\title{
Thriving in the face of adversity: Mapping experiences of international students in a South African higher education institution
}

\author{
Peace Ginika Nwokedi* and Fumane Portia M.K. Khanare \\ University of KwaZulu-Natal, South Africa \\ *Corresponding author: Email: gboriwe@gmail.com \\ Address: University of KwaZulu-Natal, Edgewood campus Pinetown, South Africa
}

\section{Background to the Study}

Migration is a global issue as it deals with more than one country. According to the Report by the United Nations Department of Economic and Social Affairs (2013) on the human population, 3 percent of the 232 million of the global human population migrate internationally to live in other countries for more than a year. In contrast, the International Organisation for Migration (IOU 2017) estimates that currently there are 244 million international migrants globally which are 3.3 percent of the world's population. In South Africa, the report conducted by Statistic South Africa (2011) during the 2011 census found that a total of 2.2 million foreigners migrate and live in South Africa annually. These foreigners include both documented and undocumented immigrants and implies that a migrant is a person who moves from their place of habitant to another (IOM 2017), often from one county to another. In this regards, international students form part of the group of people called migrants. A body of literature has shown that South Africa is not the only country that experiences student migration and that people migrate due to several reasons which could be based on the push and pull factors (Lee 2010) in which forces within the students' home country 'push' them to seek education elsewhere and forces within the host country 'pull' the students to a particular host country or institution (Lee 2010).

The report by IOU (2018) demonstrates there are 258 million immigrants of which 4.8 million are considered international students. This is supported by the study conducted by UNESCO (2016) on the global statistics of international students which also revealed that in 2016, over 4.8 million international students were enrolled for educational programs in countries all over the world including South Africa. In the case of South Africa, statistics show an enrolment of 74,000 international students in undergraduate and postgraduate levels of studies accounting for nearly 8 percent of the total student body, of which 15 percent of them are postgraduate and 6 percent of the undergraduate international students (Mokhothu and Callaghan 2018). This data suggests a high growth of international students into South African higher educational institutions beginning in 2013 (Mokhothu and Callaghan 2018).

Prior to 1994, the South African postapartheid educational system witnessed a series of transformation in educational policies which were developed, redesigned, and implemented in order to provide frameworks and guidelines to assist easy access to education for all. In 2009, the South African Government, through President Jacob Zuma, created a new ministry within the department of education known as the Department of Higher Education and Training (DHET) under the leadership of the former minister of higher education Dr. Blade Nzimande which provided a framework and policy for their higher educational institutions. Although this DHET policy framework has other objectives for developing local students, and education in general, through their policy they were able to ensure easy access for foreign and international students, as well as enhance and build appropriate diversity within their universities. This action increased the number of international students migrating into South Africa higher educational institutions as well as driving the process of internationalization within South African higher educational institutions. 
Internationalization of higher education is seen as a vital policy that deals with the combining of international activities into the teaching of higher educational institutions (Nwokedi 2015). Peace G. Nwokedi (2015) claimed that the concept of internationalization is broad and is not a new phenomenon globally. And Michael Cross, Ehpraim Mhlanga, and Emmanuel Ojo (2011) explained that internationalization is a complex, multidimensional, and fragmented process, and a response to globalization. Piyushi Kotecha (2012) posed that internationalization plays a key role in knowledge building within academia and consequently in the development of countries. Therefore, based on the evidence above, this shows the importance of exploring the experiences of international students in South African higher educational institutions.

\section{Literature Review}

\section{Defining International Students}

International students are described as a heterogeneous group of students whose common element is their status as well their intention of attaining academic excellence in a country other than their home country (Kritz 2012; Trahar and Hyland 2011; Volet and Jones 2012). This description is supported by Peace Nwokedi's (2015) and Thobeka Vuyelwa Mda's (2010) studies in South Africa, who posed that international students are a heterogeneous group of students studying in another country which is not their country of origin in order to acquire international knowledge, skills, experiences, and qualification. This paper argues that international students' diversities makes them a heterogeneous group of people as they possess diverse potentials, opinions, views, different language skills, culture, new ways of thinking, creative solutions to difficult problems and negotiation skills (Ryan and Viete 2009) making them different from their local peers and help to enhance their learning (Lee 2010), as well as being agents of geographical and cultural knowledge and not as passive recipients of knowledge (Madge, Raghuram, and Noxolo 2009).

\section{Experiences of International Students}

Dis-enabling experiences. Although the issue of migration is very challenging, there is a growing body of research that has reported on international students' diverse experiences in their host universities. For example, globally recent studies (Wang et al. 2001; Wang et al 2012.; Zhang-Wu 2018) show that international students experienced challenges within their host environments caused by different factors such as violence, racism, xenophobia, financial constraint, difficulties of acquiring visa and student permit, lack of social belonging, accommodation issues, lack of job opportunities, victimization, exclusion, and hardships which constrained their learning, growth, and development. Research by Aileen O'Reilly, Tina Hickey, and Dermot Ryan (2013) support these finds as well as highlight that international students experience sociocultural and psychological difficulties and lack of interest in internationalization. This is concurred by Lorraine Brown and Immy Holloway (2008) with Furnham (2010) who revealed in their respective studies that international students experienced loneliness as well as discrimination. Whilst Peter Townsend and Huay Jun Poh (2008) asserted that international students, due to the differences in education, finance, and cultural system of their host country, experienced difficulties within the learning environment. In a similar vein, Adam Graycar (2010) found that students experienced racial victimization, lack of intercultural interactions, and gender violence, as well as social and cultural tensions (Tarry 2010) and lack of funds (Marginson et al. 2010) in the learning environment. In addition, Jane Menzies and Rachael Barron (2014) found that language barriers and culture shock affected international students in their learning.

Naum Ogwenyi Aloyo and Arnold Wentzel (2011) indicated that international students in South African Higher Education institutions encounter psychological issues like isolation and low self-esteem. In addition, Pilot Mudhovozi (2011) and Saloshna Vandeyar (2010) also identified that language difficulties caused alienation, loneliness, and lack of social belonging on international student development. R. J. Paola and E. M. Lemmer (2013) reported that international students in South Africa experience challenges in their learning due to fluidity in their stages of cultural 
adjustment and the impact of race and gender adjustment. This view is supported by D. Y. Dzansi and L. Mogashoa (2013) who noted that international students face different learning challenges faced in South Africa due to cultural adjustment and shock, culturally insensitive classrooms, lack of collaborative classroom environment, classroom participation and communication assessment methods. Adeagbo Oluwafemi (2012) indicated that exorbitant international fees, the discriminatory policies of some universities, lack of funding and scholarship (local and international) for postgraduate students from non-South African Development Community (SADC) nations inhibited or constrained international students' learning, growth, and development in South Africa. This idea is supported by Karen MacGregor (2014), who argued that the challenges experienced by international students studying in South African include accommodation issues, financial pressures, high medical insurance cost, language, support and adjustment challenges, lack of friends, and xenophobia. Roseann Rajpal (2012) and Moise Majyambere (2012) with Elizabeth Frances Caldwell and Denis Hyams-Ssekasi (2016) also opined that international students studying in South Africa experienced several issues like xenophobia, financial difficulties, accommodation issues, language barrier, lack of communication with local students, and the difficulty in getting study visas as well as non-issuance of work permits that affected their learning difficulty.

Enabling experiences. Despite these challenges or difficulties experienced by international students in their host environment, some studies (Zhou et al. 2008; Borg and Cefai 2014; Gu, Schweisfurth, and Day 2010; Wu, Garza, and Guzman 2015) indicated that in their quest to overcome their challenges, international students' learning was enhanced, their identity also changed, and they were able to adapt, develop and achieve their educational goals. It also enabled the students to develop positive experiences and become resilient, change agents, active participants, and successful students. For instance, a considerable body of literature in the global context (Arkoudis and Tran 2010; Barnes 2011; Bista 2015; Borg and Cefai 2014; Campbell and Li 2008; Lillyman and Benneth 2014; Montogmery; Pence and Macgillivary 2009) has shown that various factors such as social support (Borg and Cefai 2014); change in their professional and personal life such as increased confidence, a better appreciation and respect for differences of others and other cultures (Pence and Macgillivray 2008); and improved knowledge, self-awareness, critical and innovative skills and attitudes enabled international students to function effectively within both their host and home countries (Gu et al. 2010).

In addition, a body of literature (Montgomery and McDowell 2009; Lillyman and Bennett 2014; Pilote and Benabdeljalil 2007; Yukl and Becker 2006) identified diverse factors inform of international network that motivated and supported international students learning in their host environment. For example, Sue Lillyman and Clare Benneth (2014) revealed that international students succeeded as an international community academically, socially and to a certain extent, emotionally because they supported one another and shared their lived experiences and knowledge of their host environment. Catherine Montgomery and Liz McDowell (2009) also discovered in their study that by sharing of knowledge, international students developed cultural understanding and engaged in joint research and development with the assistance and understanding of their host university, academic, local students and themselves. This is supported by Annie Pilote and Asmaa Benabdeljalil (2007) with Gary Yukl and Wendy Becker (2006) who found in their study that international students developed positive learning experiences through engaging and involving the academics and school management in preparing and delivery of courses which enabled them overcome their intercultural challenges and assisted them in accommodating their fellow new international students in their host university. This suggests that international students contributed positively towards the academic and economic growth of their host country. These views above correspond with the study by Ly Tran and Cate Gribble (2015) which identifies that international students through international education contributed to job creation in their host environment.

Doron Zar (2009) stresses that international students' reliance on social support from family members and other international students, as well as developing skills and acquiring critical thinking skills, receiving quality education, 
and becoming computer literate (MacGregor 2014) helped them develop successful adaptive strategies and achieve academic excellence.

In essence, the above review clearly demonstrates the need for the study which aims to contribute to the development of the body of research on the international students' experiences and in which the area of international students' experiences in Africa and in South Africa is under researched. Although there are available studies which show the complexities of doing research with international students in South Africa. However, from what the literature has revealed, much has not been said about international students' as active beings and agencies in their host environment and in particular using photovoice which is a visual methodology within qualitative research (Mitchell 2011) to generate data. In other words, this study explores and seeks to understand the international students' diverse experiences in a selected South African higher educational institution.

\section{Theoretical Framework}

This study uses the agentic capability theory of Albert Bandura (Bandura 2009; 2012) as its lens to explore international students' experiences in a South African higher educational institution. The agentic capability theory "adopts an agentic perspective toward human development, adaptation, and change" (Bandura 2006:164). This implies that international students as assets and human agency developed physically, emotionally, and holistically when they leave their home environment to study in their host environment which, in this case, is South African and their development is also based on the different enabling factors within their learning environment that assist them to adapt to their new environment and become change agents. Therefore, this made Ana Mari Cauce and Edmund W. Gordon (2011) argue that this theory deals with human agency. Furthermore, Ana Mari Cauce and Edmund W. Gordon (2011: 2) explains that "human agency is purposive, constructive, and planful and that it involves anticipating the effects of our actions, estimating our capabilities, regulating affect, and initiating effort". This suggests that international students' agency is derived from their objectives, support, positivity, intentions as well as consist their expectation of the impact of their actions based on their potentials, abilities, and skills they exercise in achieving their goals. Agency in this paper is linked to the capability and increased motivation, adaptation, adoption, self-confidence, and excellence academic achievements of international students despite their challenges in their host environments. This implies that the international students' as human agents are thinking beings and agents of change in their host environment.

Albert Bandura $(2006$; 2012) posed that to understand international students as agencies in their host environment, we should consider four attributes of an agency, such as; intentionality, forethought, self-reactiveness, and self-reflectiveness. This shows that international students have individual goals to study in South Africa which is to acquire international experience and degree as students, the learning motivation or support they receive from their host environment, their action in achieving their academic success or goals and developing self-awareness. International students' agency is further explained through three key modes of an agency such as personal (self-agency); proxy (exercised through other agents) and collective (group agency) (Bandura 2006; 2012; Ebersohn and Ferreira 2012; Khanare 2015). These imply that international students are able to exercise their influences using these different forms of human agencies which is also based on their abilities. This article shows that international students' need these three modes of human agencies in their host environment in order to operate with on a daily basis.

Meanwhile, adopting the agentic capability theory to explore the international students' as an agency in this paper shows that they are a group of people who do not exist in a vacuum but within a social structure (environment) (Krishna, 2010). On the other hand, Nicki Lisa Cole (2015) suggests agency (international students) and the structures (different factors within the environment) influences one another. This implies that the study adopted the agentic capability theory as its framework to explore international students' diverse knowledge, potentials, skills, abilities, and experiences. Drawing from the positive psychologist point of view, the international students are seen as agency who have potentials and abilities and can be influenced positively or negatively by the structures and diverse factors within 
their environment such the university policies, lecturers, peer, accommodation issues, legal policies, language, economics and political policies, churches, immigration policies etc. which could negatively or positively influence their learning. growth and development.

This article emphasizes on the relevance of using the agentic capability theory to explore and gain an in depth understanding of the experiences of international students in a South African Higher educational institution. Subsequent evidence shows that the agentic capability theory will enable the diverse experiences and knowledge of these heterogeneous group of students (international students) to be put into perspective in this study.

\section{Methodology}

The wide range of data generated from the photovoice method, self-reflective essay and focused group discussion in this study enabled the process of triangulation. Lisa Guion, David Diehl, and Debra McDonald (2011) argue that triangulation includes employing several sources of data to enhance the validity of a study. Meanwhile, this study employed a qualitative case study research design under the critical research paradigm to explore international students' experiences in a South African Higher educational institution. John W. A. Creswell (2014) defines a case study as an investigation of an enclosed instance in which the researcher employs various data generation methods to get rich and thick data within a context. Peter Rule and Vaughn John (2011:4) also contend that case study design "is a systematic and in-depth investigation of a particular instance in its context in order to generate knowledge".

This study was conducted at one of the campuses of a selected university in the Kwa Zulu-Natal province of South Africa. The sample was international students in their undergraduate and postgraduate level of study who were between the ages of 19-45 years old. The sample size of twelve $(n=12)$ participants was selected using the purposive and convenient sampling technique based on the following criteria: they have knowledge of the phenomenon and are accessible to the researcher as well as also been studying in the university where the research was conducted for more than two years and are members of the international students group (IS0). Their ages were ranged from 19 to 44 years old. The biographic information of the participants in this study is presented in Table 1 below.

Table 1: Biographic information of the participants

\begin{tabular}{|c|c|c|c|c|c|c|c|}
\hline Participants & Gender & Age & $\begin{array}{ll}\text { No. } & \text { of } \\
\text { years } & \end{array}$ & Degree & $\begin{array}{l}\text { Marital } \\
\text { status }\end{array}$ & Program & $\begin{array}{l}\text { Country } \\
\text { of origin }\end{array}$ \\
\hline 1.Friendly & Female & 19 years & 3 years & Bed & Single & $\begin{array}{l}\text { English and } \\
\text { Natural science } \\
\text { Education }\end{array}$ & Kenya \\
\hline 2. Inclusive & Male & 37 years & 3 years & $\mathrm{PhD}$ & Married & $\begin{array}{l}\text { Educational } \\
\text { leadership and } \\
\text { management }\end{array}$ & Ghana \\
\hline 3. Peaceful & Male & 39 years & 3 years & Med & Divorced & $\begin{array}{l}\text { Mathematics } \\
\text { Education }\end{array}$ & Tanzania \\
\hline 4. Safe & Female & 32 years & 3 years & $\mathrm{PhD}$ & Single & $\begin{array}{l}\text { Language and } \\
\text { Media studies }\end{array}$ & China \\
\hline 5. Caring & Male & 42 years & 3 years & PhD & Married & $\begin{array}{l}\text { Science } \\
\text { Education }\end{array}$ & Nigeria \\
\hline 6. Supportive & Male & 36 years & 3 years & $\mathrm{PhD}$ & Married & $\begin{array}{l}\text { History } \\
\text { Education }\end{array}$ & Nigeria \\
\hline 7. Secured & Male & 23 years & 4 years & $\mathrm{BEd}$ & Single & Mathematics & Burundi \\
\hline
\end{tabular}




\begin{tabular}{|c|c|c|c|c|c|c|c|}
\hline & & & & & & $\begin{array}{ll}\text { and } & \text { Life } \\
\text { science } & \\
\text { Education } & \end{array}$ & \\
\hline 8. Convenient & Female & 30 years & 2 years & Med & Married & $\begin{array}{l}\text { Educational } \\
\text { Psychology }\end{array}$ & Tanzania \\
\hline 9. Conducive & Male & 24 years & 3 years & $\mathrm{PhD}$ & Single & $\begin{array}{l}\text { Teachers } \\
\text { Development }\end{array}$ & Germany \\
\hline 10. Resourceful & Female & 46 years & 4 years & $\mathrm{PhD}$ & Single & $\begin{array}{l}\text { Curriculum } \\
\text { studies }\end{array}$ & Zimbabwe \\
\hline 11. Welcoming & Female & 27 years & 2 years & Med & Married & $\begin{array}{l}\text { Commerce } \\
\text { Education }\end{array}$ & Libya \\
\hline 12. Cooperative & Female & 44 years & 3 years & Med & Married & $\begin{array}{l}\text { Gender } \\
\text { Education }\end{array}$ & Ethiopia \\
\hline
\end{tabular}

The method employed in this study was a photovoice method, and a focus group discussion (FGDs). The photovoice method is a participatory visual methodology that is effective and aids learning by allowing successful engagement of the participants in natural discussion and in the building of democracy (Wang 2009). Photovoice is also seen as a powerful photographic technique that promotes critical dialogue and produces knowledge (Wang and Redwood-Jones 2001). It is regarded as the process of using videos or photo images by people who are discriminated against due to race, language barriers, ethnicity, class, tribe, HIV and AIDS, culture, poverty or other conditions described or portray in the different aspects of their environments and life experiences by sharing it with other people to get the attention of policymakers to either provoke or motivate for change (Carlson, Engebretson and Chamberlain 2006; Khanare 2012; Black et al. 2018). Using photovoice as a research method enabled the participants to become actively involved, engaged and participate in the study and also allowed them to make informed decision individually or as group concerning the learning, growth, and development in their host environment. Ting Wang (2010) also explains that photovoice allows people to monitor the photographic procedures in order to have a voice, think and talk about their lived experiences.

Figure 1: Nwokedi (2019) The photovoice process

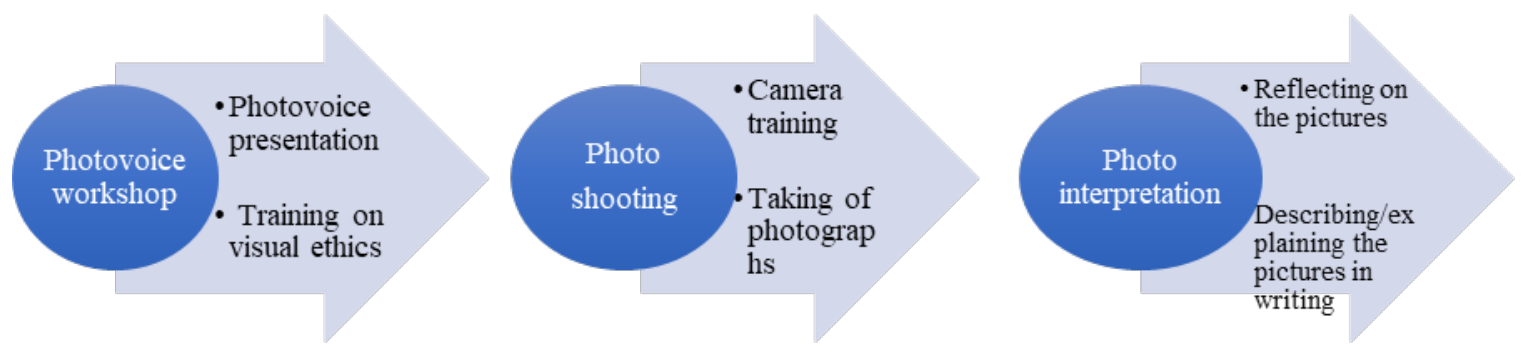

Source: Adopted from Peace Nwokedi (2019), p. 135

The process of photovoice shown above explored the experiences of international students in a South African higher educational institution and is divided into three sessions such as photovoice workshop, photo shooting, and photointerpretation sessions. The photovoice workshop which consists of the photovoice presentation and training on how visual ethics was held in a convenient venue chosen by the participants for one hour while the photo shooting which involves how to use a digital camera and take photographs also took an hour. Lastly the photointerpretation session due to time factor was done in the participants' respective homes. Although the photovoice discussion was used 
to trigger and stimulate discussion during the three focus group discussion sessions that were also conducted in a convenient venue by the researcher.

The analysis and interpretation of the data were done by reading and rereading of the participants' responses. Thematic analysis (Tesch 1990; Braun and Clarke 2013) generated the main finding of the study and these were further explored through the theoretical framework of the agentic capability theory. Meanwhile, permission to conduct the research was granted by the university ethics committee and the ethical issues such as the participants' safety, confidentiality, anonymity, and privacy were respected while conducting this study. The participant created their own pseudonyms used in this article to maintain anonymity while consents for participation and permission to audio-record the sessions was granted from the 12 international students. Meanwhile, the focus group discussion was conducted using the English language which the participants are familiar with and because it is use as the medium of communication and academic writing in all South African higher education institutions.

\section{Results}

The participants were able to identify several barriers or challenges they were currently experiencing in their learning environment which needs to be addressed within their learning context. The various challenges that are needed to be addressed were derived from the macro environment, which is the broader community (for example socio-economic and socio-cultural barrier); the microenvironment i.e. university (local students, administrative staff and university policies) and mesoenvironment (psychological challenges).

\section{The Mesoenvironment: Psychosocial Barriers}

The findings in the study revealed that all the participants experienced some psychosocial challenges or barriers in their immediate environment. These psychosocial barriers were categorised into a lack of sense of belonging; feeling of alienation and xenophobia. These made them feel isolated, develop low self-esteem and become anxious in their learning environment. The following extracts from some of the participants illustrate this:

Conducive:

... and then in terms of challenges, we also have our challenges in the sense that. ehhh. the broader scale of

South African society and the university is not as welcoming as it ought to be. There is always a feeling that as a

foreigner we are sitting on an edge, we don't belong here because we are not so welcome. This affects us psychologically because you don't know what to do not to offend them.

This view was also supported by Supportive who acknowledged that:

It shows that some of these issues are actually disturbing and cause some kind of psychological imbalance in us.

This is because it makes you feel as if you are living in a place where you are not really welcomed, where you are hated. And you know some of these things in one area or the other, they actually derail us you see. You know as a student in this context, it affects us, it affects the way we think, the way we perceive things you know when you are in a place that makes you feel you don't belong.

Another factor that revealed the participants' experiences of psychosocial barriers within their learning environment was the issue of xenophobia. Most of the participants spoke about being discriminated against because they are foreigners and are excluded from participating or taking part in some of the school programs. The following comment was made by the participants:

...the learning environment is not conducive, it makes us international students to lose focus, because of a lot of distraction like xenophobia which we experience here. I remember in 2015 when there was the xenophobia crisis at its peak, I have my fellow international students who reside in the downtown where the xenophobic activity you know was really active, most of them couldn't do anything because learning is achieved in a peaceful and conducive environment but when there are uncertainties like xenophobia surrounding our lives 
here, as we are here to study, you see we won't be able to focus on our study even to progress, the person will not be able to pay attention to anything. (Welcoming, FGD 3).

The above responses indicated that the participants experienced several psychosocial barriers that directly and indirectly affected their learning and development negatively in South Africa higher educational institution. For example, 'Welcoming' commented that the issue of xenophobia has an adverse effect on the psychological status of the international student.

\section{The Micro-environment (University)}

The international students experienced different challenges within the university environment that affected their learning and development negatively, in particular, issues connected to relationships/interactions such as the lack of social support (language difficulty) and some socio-cultural challenges were highly evident.

\section{Lack of Social Support}

The factors relating to lack of social support were identified as language difficulty and the lack of social interaction/relationship between international students and local peers. The home language of the local students and community is isiZulu, which is spoken across the KwaZulu-Natal province, which is the context where the study was conducted.

\section{Language Difficulty}

Most of the participants indicated language difficulty, as making communication and interaction with the local students and community very difficult. It also affected their learning. Not been able to speak and communicate in the local language affected the international students' integration within the campus and their host environment and limits their participation within the university.

Caring indicated:

"...sometimes you find that you are not so welcomed to the society especially I will say the ladies and most of the times the students here, they become so very difficult to interact with especially when you cannot speak the home/vernacular languages they will not relate with you. Sometimes they can come and greet you in their language and you when you ask them what do you say? The only thing they will say is that you are not speaking Zulu and leave you.

Peaceful also affirmed:

... if somebody doesn't know how to speak isiZulu, they will just exclude the person or start calling the person kwerekwere here. This makes me develop an identity crisis, I keep imagining myself am I not their fellow African person or is it because I don't speak their language. It is so terrible I swear.

Resourceful also added that:

...ehmm, the situation like going or leaving the campus here as I am resident in the campus, leaving the campus and going into the cities, simply the fact that you do not speak the language makes you feel a little bit insecure and scared to go out because you do not know who you might meet. So, not speaking the local language is what I see as a great challenge here.

The finding in this study from the above excerpts showed that the participants had trouble interacting with the local students and the local community due to the language barrier. This limited their participation and engaging with the local community. So, because of this they developed fear and became insecure in their host environment.

\section{Lack of Social Interaction}


According to the participants, the university is an environment that does not support them to socially engage with their local peers and community. To the participants, they assert that the campus/university need to create programs for them to socially integrate or socialise with the local students. The following excerpts from most of the participants illustrate this:

Supporting noted:

Ehmm in terms of the social and psychosocial life on campus, I think it is poor. Then in terms of integration into the students' life on campus as an international student with local students I think that is non-existent here and not promoted by the university. If you ask me. (FGD 2).

Another participant also inferred:

I think most of the vibrancy that takes places in the university campus in terms of social activities, then life orientation in terms of the emotional, cognitive welfare of students drawing from extracurricular activities, students' engagements, ehmm then also from the cultural point of view ehhh those things are lacking here in this campus.

According to Cooperative:

I haven't really found the environment as a social learning environment in the sense that I haven't been able to interact with the local people the way I used to like back home in my own country. I see that as a challenge, I mean it's not all about studying, learning, academic, ehhh, reading the books and making use of the facilities I mean. You see I strongly believe that, ehmm, social interaction is one of the key learning moments for me which is not promoted here for us and this affects us in adjusting and integrating into the environment.

Another factor that reflects the participants' experiences of lack of social support within the university campus was the lack of communication and interaction between them and the administrative staff of the international student's office.

Friendly also asserted that:

So ehmm also more importantly, if I will say the interaction between the support staff and the student body which is the staff in the international student's office and the international students' group I think in this kind of environment it also very weak and not good at all.

Thus, the study reveals language barriers and lack of social support (social interaction programs) between international students and the local community (local students, the administrative staff in the international student's office) as a major issue affecting international students' learning and development that needs to be addressed in order for them to grow academically and achieve their learning.

\section{Macroenvironment: Socio-cultural barriers}

Participants experienced several socio-cultural barriers that hindered their learning and development within and outside the university. These were categorized as the university exclusive policy and the government immigration policies and difficulty in acquiring a study visa to continue with their studies in their host environment. The findings in this article are that the university policy and the immigrations policy were exclusive and not inclusive. This hindered the international students from working in their host environment while the processes of acquiring visa documents/study permits also affected the students' learning and development negatively as it made them lose focus and concentration in their studies. Some of the participants' comments are as follow:

Cooperative:

... concerning the policy that you have actually mentioned you see, ehhh, the policy of the country and this university is exclusive and not inclusive because as international students we were trying to do some certain work when we came here which actually give us some little change to pay for accommodation and for our general sustenance, but you see, these policy has changed and now considers the aborigine, the locals first which is very bad.

Secured also confirmed that: 
... you know they have these policies here about when it comes to jobs because some of us are eligible but because we are international students or foreigners we won't get it but they forget that in their policy somebody who goes to school and has a study visa or a study permit has the right to work for 20hrs which is not allowed by them. One of the participants 'Safe' also spoke with intense feeling as he stressed that:

It's a struggle to even get something to do even outside, all because it is just stated in their policy and study visa that you are a student and that means you are not allowed to work but the local students in the same level with you can work. I don't know how they will be able to conscientize people to tell them that when you are a student you cannot work and earn a meagre living for yourself here.

Apart from the exclusive policies limiting the international students from working, the participants also identified different difficulties they experienced during the process of acquiring their study documents/ visas/permits that demoralize them and have a negative effect on their learning. The subsequent responses indicate the participants' views on the issue of study visa:

Inclusive:

... in other universities permits are facilitated by the international office but here as a student you are the one doing it by yourself and the process of doing those things demoralises students first of all because just the hurdles of getting a document in this country is not easy and then you have an institution that is supposed to help you but the institution is leaving everything it to you.

Conducive also stated that:

This issue of visa permit is hindering one's way of learning here. For us to be here, that means we need to have a valid document and if you don't have that it is always scary to move around. I think the university needs to be a bit more supportive so that our learning can also be fruitful in order for us to finish with our studies here.

Lastly, Welcoming points out that:

One of the things limiting us, is in the term of all these visa issues, you know when you go to renew your visa, there are so many other changes and they keep on changing policies every time. Some people ae denied visa just because of silly things that are not included in their website.

A closer examination of the participants' responses above has revealed several socio-cultural factors within the micro environment such as the exclusive university and immigration policies and the difficulty experienced by international students in acquiring study visa/permit which needs to be addressed so as to make the environment conducive for international students' learning and growth.

\section{Socio-economic barriers}

The participants identified various socio-economic barriers within the macro-environment that affected their learning and development negatively in the South African higher education institution. These socio-economic challenges were related to financial constraints identified by international students as a major barrier to their learning and development in the South African higher education institution. These financial challenges were categorized as lack of funding and scholarships, lack of job opportunities, as well as accommodation fees. The lack of job opportunities and lack of funding/scholarship was found to be the most prevailing issues affecting participants' learning and development. This was revealed in the following participants' quotes below:

Cooperative asserted:

Most of the universities that I know from most part of the world, by the time someone $\quad$ reaches $a \quad P h . D$. or master's level, you will be teaching undergraduates and also get scholarship or funding to continue with your studies. There is no way you will be doing a Ph.D. or master's program that they don't give you the scholarship to take care of yourself and tell you that this scholarship is a full time and you are not supposed to work. Apart from that, they make sure that if you have no scholarship, the school, itself can create an environment 
where you can work or do something at least for yourself which is not applicable here because they will tell you are not a local.

Another of the participant indicated:

I want to talk about funding. Not having funding is a hindrance to our learning and development here, because you find out that just like my colleague has said you find out that ehh we have to be looking for modules to teach, and do marking, so that we can make some income to pay our bills for residence and sustenance and some stuff like that even books. (Secured).

The lack of job opportunities within the university and outside the university environment negatively affected their learning and development. Peaceful experienced difficulty in getting a job within and outside the university environment that affected him emotionally because he was unable to provide for his family as the bread winner as he highlights:

This environment for a start, it is difficult to get a job here and there are many issues that are relating to finding job opportunities here. Some of us has got families, we are no more like undergraduate students. So, sometimes when we go to look for work here in school and outside let say in shops like Shoprite, Clicks, Debonairs they will tell you categorically we don't have space for you people here. We can't get job opportunities here and they do not care whether you have a family or not here. The people believe you have come to steal their job, they will even call us kwerekwere. This issue is affecting me because I have to think about myself and family on how we are going to survive here and pay all our bills. (Peaceful).

In addition, another participant 'Resource' noted:

If you take your CV and everything you won't get a job outside. Even if the university advertises for a job inside, they will just tell you clearly please we don't have any place for you as a foreigner. It's clear they don't even say, they don't mince words. I have called companies; they have got my $C V$ and everything and they just told me that unfortunately because of my status and that's is their only reason not because of anything.

Furthermore, international students also identified the incessant increase in accommodation/residence fees as a barrier to their learning. The participants revealed that the high cost of residence fees causes a high cost of living for them in their host environment which is a challenge and affected their learning and development negatively. Most of the participants expressed the view that the university should reduce the accommodation fees so that they could finish their studies within the given time. The following excerpts revealed the participants' views on the accommodation/residence fees.

...also, ehhh, what can hinder us like ehmm is still had to do with the cost of living, just like residence now, it is every year that the fees are going up. When I started it was around R23000. Right now, it is R28 000 a year and by next year maybe it is going to R30 something thousand rands, and I heard it is going to go to over thirty something plus. So that's a hindrance to our learning. And now they have to give us rules that we must finish within four years, so we have to like to make a plan. (Conducive).

Friendly also highlighted that:

Then also we can think about the issue of high fees in term of residence fees even though the university has made provision or had made a lot of sacrifice to give some sort of fee remission policies to accommodates students who are doing full research and their studies here but also I would personally argue that the fees are quite high, especially residence fees are quite high for us, so it is a bit of a challenge you know coming to terms with the huge amount of money you get to pay every single year to live in the school residence. (FGD 1).

Some of the participants revealed that the lack of finances to pay high accommodation fees affects them psychologically and made them lose concentration in their study, as noted below.

Conducive also has this to say:

... but as u can see now that we are worried on how to sustain ourselves here because there is no funding for us most of us here are self-funded which affects our study negatively. 
Based on the above findings, the excerpts from the international students above revealed that they experienced several financial barriers within their learning environment that affected their learning and development negatively in the South African higher educational institution.

\section{Discussion}

The research shows the challenges experienced by international students that need to be addressed. Drawing from the agentic capability theory of Bandura $(2006 ; 2012)$ the challenges experienced by the students seem to be more external and located at the macro and microenvironment. This implies that international students find it difficult to interact and interrelate with the local people or community within the macro and microenvironment. This shows a lack of interaction outside their proxy agency. Moreover, the findings revealed the challenges experienced by international students in this context surpass what they already possess (capacity/ability/skills), which could make them be passive agents rather than active agents. Thus, international students need a conducive learning environment to address several challenges within their macro environment (socio-economic and socio-cultural barriers); micro-environment (language difficulty and lack of social integration) and imposed environment (psychosocial barriers) in which they are currently experiencing in South African higher educational institution.

First and foremost, the study reveals that international students experienced several psychological issues such as lack of sense of belonging, feelings of alienation, low self-esteem, anxiety, and xenophobia in the context of HIV and AIDS. These challenges made the participants lose focus academically, feel stressed and depressed, develop low self-esteem, regress academically, have psychological imbalances and lose concentration in their studies. Generally, in the literature, it is found that international students experience various psychological barriers such as isolation, low self-esteem (Aloyo and Wentzel 2011), discrimination (Furnham 2010); loneliness (Brown and Holloway 2008) and exclusion (Dzansi and Mogashoa 2013). The findings also indicate that due to these psychological challenges, the students' self-esteem and academic performance are affected negatively.

On the other hand, in the microenvironment which is the university environment. According to the findings, the participants' verbatim excerpts indicated the lack of social support and some socio-cultural barriers international students experienced in South African higher education institution that affected their learning negatively. Thus, the findings show that international student's abilities to learn and excel academically can be affected by the school environment when they are socially constrained. The findings showed that international students feel excluded within and outside their learning environment due to language barriers that affect their learning and relationships with the local community. Jacqui Campbell and Mingsheng Li (2008) with Menzies and Baron (2014) find that international students experience academic issues caused by language difficulties in their learning environment. These findings from this study also revealed that these issues make international students develop fear and insecurity. On the other, Pilot Mudhovozi (2012) with Saloshna Vandeyar (2010) found that language issues caused alienation, loneliness, and lack of social belonging on international students' learning experiences.

Meanwhile, another factor that is evident is the socio-cultural barriers that affected international students' learning and development in South African higher education institutions. According to the findings, a key social-cultural issue was the exclusive university and immigration policies that hindered international students from finding jobs and working within and outside the university environment as well as the strict visa policies and the difficulties they experienced in acquiring their study visa/permit. The finding is in line with the study by Nwokedi (2015), who found strict and exclusionary immigration policies and the difficulty of acquiring students' visas and permits constrained international students' efforts in participating in some events and in interacting with people. Moise Majyambere (2012), Roseanne Rajpal (2013) with Elizabeth Frances Caldwell and Denis Hyams-Ssekasi (2016) report that international student's experience strict visa laws and difficulties in acquiring a study visa/permit that affects their learning performances and prevents them from working or restrict them to work for lesser hours. 
Thus, in the macro environment, international students experience several social economic barriers such as financial constraints, which contribute a major threat to their learning and development in the context of HIV and AIDS. These socio-economic challenges (financial constraints) are identified in the study as lack of funding and scholarships, lack of job opportunities and high accommodation/residence fees that affect the students' learning negatively and make them feel discriminated and rejected within their host environment. The findings in this study corroborate the study by Adeagbo Oluwafemi (2012) in South Africa, which found extortionate international fees and lack of funding and scholarships as the major financial constraints experienced by international students in South Africa. Additionally, international students also experienced financial constraint due to the excessive cost of accommodation (MacGregor 2014; Nwokedi 2015) in uncomfortable environments, lack of funds (Marginson et al. 2010) and high medical insurance costs (Nwokedi 2015; Oluwafemi 2012). The findings show that financial constraint affects international students psychologically and cause them to lose concentration in their study. Despite experiencing several financial constraints, in contrast, Ly Tran and Cate Gribble (2015) argue that international students contribute to the economic growth of their host country through fees -school fees, accommodation and hospitality - and increased travel and tourism.

Significantly, this study makes a methodological and theoretically contribution towards the existing body of knowledge of research on international students' education and mobility on human development. The study showed that international students are not passive beings but active individuals who were amazed at their elevated personal development and growth as well as their contribution towards the growth and development of other people in their learning environment. It also gives voice and opportunity to international students to express their views and make informed decisions about their lives and experiences. Therefore, the voices of international students who have been silent or unheard especially from a different context which is from the higher education perspective is revealed concerning issues that concern them. In addition, employing photovoice method in this study provided a visual representation of international students' experiences look like and not only on what is written about their live experiences. This will enable people such as the policy makers and university management to actually see what the international students are experiencing and envisage how they and will address or improve them.

\section{Conclusion and Recommendation}

The study has revealed the different inhibiting elements/factors (inhibitors) within the international students' learning environment (meso, micro, and macro) that affected their migration, settlement, learning, growth, and development in South African higher education institutions. Furthermore, according to the findings in this theme, these inhibiting elements or factors, which were identified as anxiety, xenophobia, low self-esteem, stress, language difficulties, lack of job opportunities, financial difficulties and visa issues etc. have made international students lose focus in their studies, become psychologically imbalance, feel excluded and discriminated against. However, the participants indicated that addressing these inhibiting elements that they are currently experiencing will enable them to finish their studies within the specified time frame, enhance and shape their learning, growth, and development within the South African higher educational institution. Succinctly, enhancing international student's wellbeing and addressing the challenges they are experiencing will ensure that they learn better, attain and achieve their academic goals and develop holistically in South African Higher educational institutions. The implication of the findings is that the challenges experienced by the international students could have an adverse effect on the school rankings and publications input and might also discourage potential students to come and study in this university. Therefore, South African higher educational institutions need to provide an enabling learning environment for these group of students by ensuring they easily resolve and respond to international students' needs and challenges as well as enable them to tap into the hidden potential and skills that they possess. 


\section{Acknowledgement}

I express my sincere gratitude and appreciation to God, my family, friends and to Dr. Fumane P. Khanare for the financial, emotional and intellectual support and guidance in conducting this study

\section{References}

Aloyo, Naum Ogwenyi, and Arnold Wentzel. 2011. "The potential skills contribution of international students to South Africa.” Africa Education Review 8(2): 336-354. https://doi.org/10.1080/18146627.2011.603230.

Arkoudis, Sophie, and Ly Thi Tran. 2010. "Writing blah, blah, blah: Lecturers' approaches and challenges in supporting international students." International Journal of Teaching and Learning in Higher Education, 22(2):169-178. http://hdl.handle.net/10536/DRO/DU:30055902.

Bandura, Albert. 2006. "Toward a psychology of human agency". Perspectives on Psychological Science, 1 (2): 164-180. http://doi/abs/10.1177/1745691617699280.

Bandura, Albert. 2009. "Cultivate self-efficacy for personal and organisational effectiveness". Handbook of principles of organisation behavior 2(1): 11-21.

Bandura, Albert. 2012. "On the functional properties of perceived self-efficacy revisited." Journal of Management, 38(1): 9-44.

Barnes, Bronwyn. 2011. "Teachers' perceptions and understanding of diversity and inclusive $\quad$ education: A case study”. M.Ed. Thesis (Unpublished). Stellenbosch: Stellenbosch, University.

Bista, Krishna. 2015. “Asian international students' college experience: Relationship between quality of personal contact and gains in learning." Journal of International and Global Studies, 6(2): 39-54.

Black, Gillian F., Alun Davies, Dalia Iskander, and Mary Chambers. 2018. "Reflections on the ethics of participatory visual methods to engage communities in global health research." Global Bioethics, 29(1): 22-38. Retrieved from https://www.tandfonline.com/loi/rgbe20.

Borg, Claire, and Carmel Cefai. 2014. "Stress, health and coping among international students at the University of Malta." Second Monogram in Resilience \& Health. Malta: Center for Resilience and Socio-Emotional Health, University of Malta. Retrieved from http://www.um.edu.mt/cres/publications.

Braun, Virginia, and Victoria, Clarke. 2014. Thematic analysis. In Encyclopedia of Critical Psychology, edited by T. Teo, 1947-1952. New York: Springer.

Brown, Lorraine, and Immy Holloway. 2008. "The adjustment journey of international postgraduate students at an English university: An ethnographic study." Journal of research in International Education, 7(2):232-249. DOI: $10.1177 / 1475240908091306$.

Caldwell, Elizabeth Frances, and Denis Hyams-Ssekasi. 2016. "Leaving home: The challenges of Black-African international students prior to studying overseas.” Journal of International $\quad$ Students, $\quad 6(2)$ : $\quad 588-613$. http://jistudents.org/.

Campbell, Jacqui, and Mingsheng Li. 2008. “Asian students' voices: An empirical study of Asian students' learning experiences at a New Zealand university." Journal of Studies $\quad$ in international education, 12(4): 375396. https://doi.org/10.1177/1028315307299422

Carlson, Elizabeth D., Joan Engebretson, and Robert M. Chamberlain. 2006. "Photovoice as a social process of critical consciousness." Qualitative health research, 16(6): 836- 852. Doi:10/177/1049732306287525.

Cauce, Ana Mari, and Edmund W. Gordon. 2012. "Toward the measurement of human agency and the disposition to express it." Gordon commission on the future of educational assessment, Princeton Educational Testing Service. Retrieved from ordoncommissionblog.wordpress.com/commissioned-papers/toward-themeasurementof-human-agency-and-the-disposition-to-express-it/. 
Cole, Nicki Lisa. 2015. Agency: A sociological definition. Retrieved from http://sociology.about.com/od/A_Index/fl/Agency.htm

Creswell, John W. 2014. A concise introduction to mixed methods research. Thousand Oaks: Sage publications.

Cross, Michael, Ehpraim Mhlanga, and Emmanuel Ojo. 2011. "Emerging concept of internationalisation in South African higher education: Conversations on local and global exposure at the University of the Witwatersrand (Wits)." Journal of Studies in International Education, 15(1):75-92. DOI:10.1177/102831530933463 http://jsie.sagepub.com.

Department of Economic and Social Affairs, United. Nations. 2013. "World population prospects: $\quad$ the 2012 revision." Population division of the department of economic and social affairs of the United Nations Secretariat, New York 18. Retrieved from https:/www.un.org/en/development/desa/publications/worldpopulation-prospects- the-2012-revision.html

Dzansi, Dennis. Yao., and Lesang Grace. Mogashoa. 2013. "International Students in the Classroom: A South African Evidence of Impact on Lecturer and Domestic Student Classroom Practices and Classroom Effectiveness." Journal of Sociology and Social Anthropology, 4(3): 227-237. https://doi.org/10.1080/09766634.2013.11885600

Ebersohn, Liesel, and Ronel Ferreira. 2012. "Rurality and resilience in education: Place-based partnerships and agency to moderate time and space constraints." Perspectives in education, 30 (1): 30-42.

Furnham, Adrian. 2010. "Culture shock: Literature review, personal statement and relevance for the South Pacific." Journal of Pacific Rim Psychology, 4 (2): 87-94. https://doi.org/10.1375/prp.4.2.87.

Graycar, Adam. 2010. Racism and the tertiary student experience in Australia. A paper presented at the Academy of the Social Sciences in Australia. Canberra, Australia. Retrieved from https://www.humanrights.gov.au/ourwork/race- discrimination/publications/racism-and-tertiary-student-experience-australia-adam.

Gu, Qing, Michele Schweisfurth, and Christopher Day. 2010. 'Learning and growing in a 'foreign' context: Intercultural experiences of international students." Compare, 40 (1): 7-23. https://doi.org/10.1080/03057920903115983.

Guion, Lisa. A., David C. Diehl, and Debra McDonald. 2011. "Triangulation: Establishing the validity of qualitative studies. University of Florida IFAS Extension." Online Document. Retrieved from https://journals.flvc.org/edis/article/view/108267.

International Organisation for Migration (IOM). 2017. 'Migration and migrants: A global overview'. In IOM (2017) World Migration Report 2018. IOM: Geneva. Retrieved fromhttps://publications.iom.int/books/worldmigration-report-2018-chapter-2 migration-and-migrants-global-overview.

International Organisation for Migration (IOM). 2018. 'Global migration indicators 2018'. IOM: Geneva. Retrieved from www.migrationdataportal.org.

Khanare, Fumane. 2012. "Schoolchildren affected by HIV in rural South Africa: schools as environments that enable or limit coping." African Journal of AIDS Research, 11(3): 251-259. https://www.tandfonline.com/loi/raar20.

Khanare, Fumane. 2015. 'Rethinking care and support of 'vulnerable' learners in the age of HIV and AIDS: An artsbased approach'. Ph.D. thesis (Unpublished). Port Elizabeth.: Nelson Mandela Metropolitan University.

Kotecha, Piyushi. 2012. "Introduction: Making internationalisation work for higher education in Southern Africa". In Internationalisation in higher education perspectives from the Global South, edited by P. Kotecha, 1-3. Johannesburg: Southern African Regional Universities Association (SARUA). http://www.jielusa.org/home.

Krishnan, Vijaya. 2010. "Early child development: A conceptual model.” In Early Childhood Council Annual Conference, pp.1-17. Retrieved

http://www.cup.ualberta.ca/wp.../ConceptualModelCUPwebsite_10April13.pdf

Kritz, Mary M. 2012. "Globalization of higher education and international student mobility." In United Nations expert group meeting on trends in migration: demographic aspects population division. Retrieved from http://www.un.org/esa/population/meetings/EGM_MigrationTrends/KritzPresentatio nFinal. 
Lee, Jenny J. 2010. "International students' experiences and attitudes at a US host institution: Self-reports and future recommendations." Journal of Research in International $\quad$ Education, $\quad 9(1)$ : $\quad$ 66-84. $\quad$ DOI: 10.1177/1475240909356382. http://jri.sagepub.com.

Lillyman, Sue, and Clare Bennett. 2014. "Providing a positive learning experience for international students studying at UK universities: A literature review." Journal of Research in International Education, 13(1): 63-75. DOI: $\quad 10.1177 / 1475240914529859$. http://jri.sagepub.com.

MacGregor, Karen. 2014. Major survey of international students in South Africa. University World News, 333. Retrieved from http://www.universityworldnews.com/article.php?story=20071206163532421

Madge, Clare, Parvati Raghuram, and Patricia Noxolo. 2009. "Engaged pedagogy and responsibility: A postcolonial analysis of international students." Geoforum, 40(1): 34-45. doi: 10.1016/j.geoforum.2008.01.008.

Majyambere, Moise. 2012. 'Information needs and information seeking behaviour of international students at the University of KwaZulu-Natal, Pietermaritzburg Campus'. Master of Information thesis, (Unpublished). Pietermaritzburg: University of KwaZulu- Natal.

Marginson, Simon, Chris Nyland, Erlenawati Sawir, and Helen Forbes-Mewett. 2010 "International student security". Cambridge: Cambridge University Press.

Mda, Thobeka Vuyelwa. 2015. "African international students in South African universities". In a home away from home? International students in Australian and South African Higher education, edited by I. Synder, and J. Nieuwenhuysen, 146-166. Clayton, Victoria: Monash University Publishing.

Menzies, Jane L., and Rachael Baron. 2014. "International postgraduate student transition $\quad$ experiences: $\quad$ The importance of student societies and friends." Innovations in Education and Teaching International, 51(1):84-94. https://doi.org/10.1080/14703297.2013.771972.

Mitchell, Claudia. 2011. Doing visual research. Thousand Oaks, CA: Sage publishers.

Mokhothu, Thabang M., and Chris W. Callaghan. 2018. "The management of the international student experience in the South African context: The role of sociocultural adaptation and cultural intelligence". Acta Commercii, 18(1): 1-11. http://dx.doi.org/10.4102/ac.v18i1.499.

Montgomery, Catherine. 2010. Understanding the international student experience. New York: Macmillan International Higher Education.

Montgomery, Catherine, and Liz McDowell. 2009. "Social networks and the international student experience: An international community of practice?” Journal of Studies in International Education, 13(4):455-466. https://doi.org/10.1080/14330237.2011.10820458

Mudhovozi, Pilot. 2011. "Adjustment experiences of international students at a South African university." Journal of Psychology in Africa, 21(2): 293-296. https://www.tandfonline.com/loi/rpia20.

Nwokedi, Peace G. 2015. 'International students' experiences of learning in a selected South African University'. M.Ed. Thesis (Unpublished). Durban: University of KwaZulu- Natal.

Nwokedi, Peace G. 2019. 'An enabling learning environment for International students in the context of HIV and AIDS'. PHD Thesis (Unpublished). Durban: University of KwaZulu-Natal.

O'Reilly, Aileen, Tina Hickey, and Dermot Ryan. 2013. "Higher education professionals' perspectives on international student experiences of life and learning in Ireland: a qualitative study.” Irish Educational Studies, 32(3): 355-375. https://doi.org/10.1080/03323315.2013.826334

Oluwafemi, Adeagbo. 2012. "International postgraduate students from Africa are struggling”. University $\quad$ World News (218). Retrieved from http://www.universityworldnews.com/article.php?story=20120420173341253>

Paola, Roberta. James, and Eleanor. M. Lemmer. 2013. “Not merely a matter of academics': Student experiences of a South African university as study-abroad destination.” Africa Education Review, 10(1):80-96. https://doi.org/10.1080/18146627.2013.786871. 
Pence, Holly M., and Ian K. Macgillivray. 2008. "The impact of an international field experience on preservice teachers". Teaching and teacher education, 24(1): 14-25. https://doi.org/10.1016/j.tate.2007.01.003.

Pilote, Annie, and Asmaa Benabdeljalil. 2007. "Supporting the success of international students in Canadian universities." Higher Education Perspectives, 3(2):24-46. $\quad$ hep.oise.utoronto.ca.

Rajpal, Roseann. 2012. "Educational Journeys of International Postgraduate Students Studying at UKZN (University of KwaZulu-Natal): A Narrative Inquiry." $\mathrm{PhD}$ dissertation (unpublished), Durban: University of KwaZulu-Natal.

Rule, Peter, and Vaughn John. 2011. "Your guide to case study research”. Pretoria: Van Schaik.

Ryan, Janette, and Rosemary Viete. 2009. "Respectful interactions: Learning with international students in the English-speaking academy.” Teaching in Higher education, $\quad 14 \quad$ 303-314. https://doi.org/10.1080/13562510902898866

South African Department of Higher Education and Training (DHET). 2014. "White Paper for Post Pchool Education and Training: building an Expanded, Effective and Integrated Post School System”. Pretoria: Government Printers.

Statistics South Africa. 2015. “Census 2011: Migration dynamics in South Africa.” Statistics South Africa. Pretoria: Statistics South Africa.

Tarry, Estelle. 2011. "Is West really best? Social and cultural tensions international students experience having studied at British universities.” Journal of further and higher education, $\quad 35(1)$ : https://doi.org/10.1080/0309877X.2010.540316

Tesch, Renata. 1990. “Types of qualitative analysis.” In Qualitative Research edited by R. Tesch, 77-102. NewYork: Falmer press.

Townsend, Peter, and Huay Jun Poh. "An exploratory study of international students studying and living in a regional area." Journal of Marketing for Higher Education, 18(2): 240- 263. https://doi.org/10.1080/08841240802487411.

Trahar, Sheila, and Fiona Hyland. 2011. "Experiences and perceptions of internationalisation in higher education in the UK". Higher Education Research \& Development, 30(5): $\quad$ 623-633. https://doi.org/10.1080/07294360.2011.598452

Tran, Ly, and Cate Gribble 2015. Foreign students have a valuable contribution to make. University World News (387). Retrieved from http://www.universityworldnews.com/article.php?story=20151020202131169.

United Nations, 2013. "World Population Prospects: The 2012 Revision, Highlights and Advance Tables (Working Paper No. ESA/P/WP. 228).” Retrieved from https://population.un.org/wpp/Publications/Files/WPP2012_HIGHLIGHTS.pdf.

United Nations Educational, Scientific, and Cultural Organization (UNESCO). 2016. "Global Flow of TertiaryLevel Students. " Retrieved from (http://www.uis.unesco.org/Education/Pages/international-student-flowviz.aspx)

UNESCO, UIS. 2016. “Education: Outbound Internationally Mobile Students per Host Region.” Retrieved from. http://data.uis.unesco.org/Index.aspx?queryid=172World Bank. 2018. Outbound students by income.

Vandeyar, Saloshna. 2010. "Educational and socio-cultural experiences of immigrant students $\quad$ in South African schools.” Education Inquiry, 1(4):347-365. https://doi.org/10.3402/edui.v1i4.21950.

Volet, Simone, and Cheryl Jones. 2012. "Cultural transitions in higher education: Individual adaptation, transformation and engagement." In Transitions across schools and cultures, edited by S. Karabenick and T. Urdan (Eds). 241-284. Bingley: Emerald Group Publishing Limited.

Wang, Caroline C., and Yanique A. Redwood-Jones. 2001. "Photovoice ethics: Perspectives from Flint photovoice." Health Education \& Behavior, 28(5): 560-572. https://doi.org/10.1177/109019810102800504. 
Wang, Kenneth T., Puncky Paul Heppner, Chu-Chun Fu, Ran Zhao, Feihan Li, and Chih-Chun Chuang. 2012. "Profiles of acculturative adjustment patterns among Chinese international students." Journal of Counselling Psychology, 59(3): 424-436. DOI: 10.1037/a0028532.

Wang, Ting. 2010. "Using photovoice for assessment in teacher education and examining the impacts of globalisation on China." In AARE 2009 International Education Research Conference. Australian Association for Research in Education (AARE).

Wang, Yu-Wei, Jun-chih Gisela Lin, Lan-Sze Pang, and Frances C. Shen. 2007. "International Students from Asia.”. In, the Handbook of Asian American psychology edited by F.T.L. A. Leong, A. Ebreo, L. Kinoshita, A. G. Inman, L. H. Yang, and M. Fu, 245-261. Thousand Oaks, CA: Sage.

Wu, Hsiao-ping, Esther Garza, and Norma Guzman. 2015. "International student's challenge and adjustment to college." Education Research International 2015 (1). 1-9. https://doi.org/10.1155/2015/202753.

Yukl, Gary A., and Wendy S. Becker. 2006. "Effective empowerment in organizations". Organization Management Journal, 3(3):210-231. https://www.tandfonline.com/loi/uomj20.

Zar, Doron. 2009. "International students from Africa: the impact that living in South Africa has on one's sense of identity." PhD dissertation (Unpublished), Johannesburg: University of the Witwatersrand.

Zhang-Wu, Qianqian. 2018. "Chinese International Students' Experiences in American Higher Education Institutes: A Critical Review of the Literature.” Journal of International $\quad$ Students, $\quad$ 1173-1197. http://jistudents.org/doi: 10.5281/zenodo.1250419.

Zhou, Yuefang, Divya Jindal-Snape, Keith Topping, and John Todman. 2008. "Theoretical models of culture shock and adaptation in international students in higher education." Studies in Higher Education, 33(1):63-75. https://doi.org/10.1080/03075070701794833. 